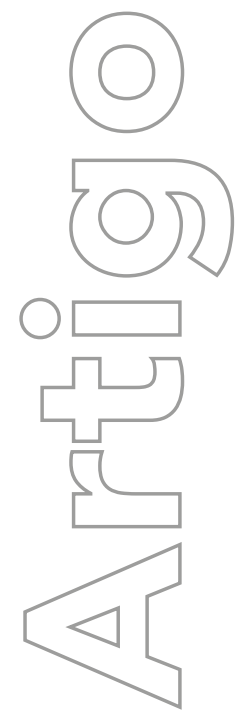

revista

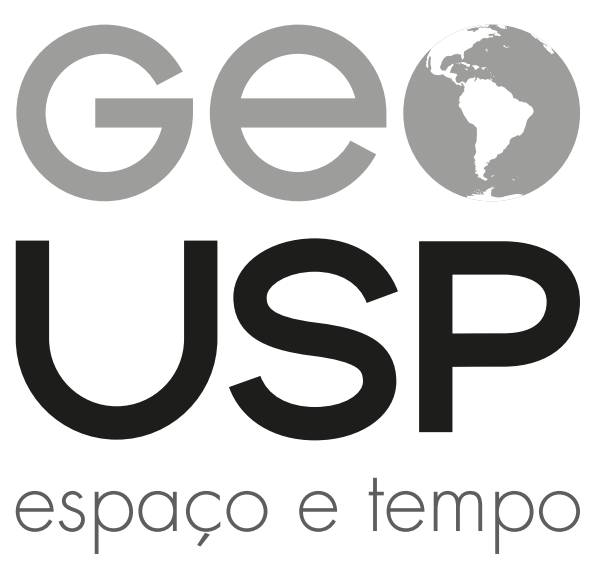

Volume $25 \cdot n^{\circ} 3$ (2021)

ISSN 2179-0892

\section{A cidade sob "títulos": das notícias aos livros notariais da propriedade imobiliária na capital parahybana (1910-1930)}

Wilma Guedes de Lucena

Universidade do Estado de Minas Gerais. Carangola.

Minas Gerais. Brasil profwilma.geo@gmail.com (1) 0000-0001-9310-4623

e-184536

Como citar este artigo:

LUCENA, W. G. A cidade sob "títulos": das notícias aos livros notariais da propriedade imobiliária na capital parahybana (1910-1930). Geousp, v. 25, n. 3, e-184536, dez. 2021. ISSN 2179-0892.

Disponivel em: https://www.revistas.usp.br/geousp/article/ view/184536. doi: https://doi.org/10.11606/issn.2179-0892. geousp.2021.184536.

\section{(c) (i)}

Este artigo está licenciado sob a Creative Commons Attribution 4.0 Licence 


\section{A cidade sob "títulos": das notícias aos livros notariais da propriedade imobiliária na capital parahybana (1910-1930)}

\section{Resumo}

Este artigo propõe um conjunto de fontes históricas que ajudam a identificar e desvendar práticas financeirizadas na produção das cidades nas primeiras décadas dos novecentos, incluindo cidades periféricas como a Parahyba. Essas práticas se basearam em instrumentos jurídicos e financeiros criados naquele momento histórico, voltados ao mercado de crédito e que envolviam, entre outros bens, a propriedade imobiliária. Os referidos instrumentos - letras hipotecárias, títulos de empréstimo ou de ações, entre outros - se desdobravam de escrituras públicas registradas nos livros notariais dos cartórios e eram estampados em anúncios e notícias dos jornais da época. Aqui, são tratados não apenas pelas informações e dados empíricos que nos fornecem, mas também como instrumentos do processo de mobilização da cidade como mercadoria.

Palavras-chave: Cidade da Parahyba. Escrituras e jornais. Primeira República. Práticas financeirizadas. Valorização do espaço.

\section{The city under "titles": from news to notary books on real estate in capital parahybana (1910-1930)}

\footnotetext{
Abstract

This article proposes the use of a set of historical sources, taken as a potential enabler to identify and disclose financial practices at the outset of the twentieth century targeting the production of cities, including those peripheral ones, such as Parahyba. These practices were carried out rooted in legal and financial tools and were forged in this precise historical context. It aimed at the credit market, and among other liquid assets, involved real estate. Such instruments, as mortgagebacked bonds, loan and equity security, unfolded from public deeds among notary's office papers, being also found printed in advertisements and news of those years newspapers. All these documents will be treated here not only by the information
} 
and empirical data they provide us but primarily because they were instruments in the process of space valuation, expressly in making Parahyba a commodity.

Keywords: City of Parahyba. Deeds and newspapers. First Republic. Financialized practices. Space valuation.

\section{La ciudad bajo los "títulos": de las noticias a los libros notariales de las propiedades inmobiliarias en capital parahybana (1910-1930)}

\section{Resumen}

Este artículo propone un conjunto de fuentes históricas que ayudan a identificar y develar la concreción de prácticas de financierización en la producción de ciudades durante las primeras décadas del siglo XIX, incluyendo ciudades periféricas como Parahyba. Tales prácticas fueron implementadas con base en instrumentos legales y financieros, creados en el momento histórico citado, dirigidos al mercado crediticio y que involucraron, entre otros activos, propiedades inmobiliarias. Dichos instrumentos, tales como pagarés hipotecarios, préstamos y valores patrimoniales, entre otros, se desarrollaron a partir de las escrituras públicas inscritas en los libros de las notarías públicas, así como se imprimieron en anuncios y noticias en los periódicos de la época. Aquí, estos documentos son tratados no sólo por la información y los datos empíricos que nos brindan, sino también para discutir cómo ellos mismos fueron instrumentos en el proceso de movilización de la ciudad como mercancía y, por tanto, de valorización del espacio.

Palabras clave: Ciudad de Parahyba. escrituras y periódicos. Primera República. Prácticas de financierización. Valorización del espacio.

\section{Introdução}

Entre as décadas de 1910-30, os leitores do jornal A União recebiam nas primeiras horas do dia as últimas notícias sobre o conjunto de transformações e reformas urbanísticas que ocorriam na cidade da Parahyba. ${ }^{1}$ As polêmicas em torno do serviço de abastecimento de água, da distribuição de energia elétrica e das inúmeras demolições das casas de palha, antigos prédios públicos e templos

1 Sobre as transformações urbanas na capital parahybana nas primeiras décadas do século XX, vale consultar os trabalhos de Maia (2006, 2010, 2016), Trajano Filho (2006), Vidal (2004, 2016) e Sá (2009, 2016). 
religiosos, eram degustadas em mesas de cafés, alardeadas aos berros no ponto final dos bondes, ou mesmo compartilhadas em rodas de conversa audíveis até para os não letrados que ali circulavam. Ocorria que entre uma polêmica e outra, ou entre as notícias das não tão distante guerra mundial, dominação alemã ou negócios estadunidenses, difundiam-se também propagandas, anúncios, promessas de toda ordem. ${ }^{2}$ Tratava-se de informar a cotação do algodão, café e outros produtos exportados e importados, bem como propagar as mercadorias francesas, inglesas e tantas outras.

Contudo, nessas páginas, a cidade também aparecia na forma jurídica de imposto predial, escrituras ou apólices nominativas e ao portador, na forma de anúncios de aluguéis e venda de imóveis e mesmo na promessa da construção de habitações mais salubres e modernas. Em outras palavras, ela era produzida, mas também mobilizada antecipadamente na forma de renda fundiária e de juros. ${ }^{3}$

Essa cidade-mercadoria, para colocar nos termos de Rodrigues (2019), não circulava apenas entre as mãos dos leitores d'A União e de outros jornais. Aos pedaços, ela transitava em bolsos de especuladores que viajavam entre a Parahyba e o então Distrito Federal - Rio de Janeiro; cambiava entre uma gaveta e outra de tabeliães, proprietários e credores de toda sorte; percorria trajetos internacionais nas mãos de comissários e era anunciada como espaço "vazio" a ser ocupado/dominado. Assim, diferentemente do que acreditava o tabelião Vaz Nunes, ${ }^{4}$ a cidade e os imóveis nela fixados eram transportados pelas ruas segundo os interesses de incorporadores, investidores, comerciantes etc. Nesse trânsito de páginas de jornais, de escrituras em livros notariais, de títulos de dívidas, de letras hipotecárias e de apólices, o canto da sereia que soava mavioso aos ouvidos dos leitores era o de comprar a casa própria; extrair dividendos; e, por conseguinte, embolsar renda e juros.

Ao baralhar o conjunto das informações dispostas nos tipos de documentos supramencionados, o leitor atento pode reconhecer toda sorte de práticas especulativas ${ }^{5}$ (Lucena, 2020) próprias do capital fictício (Harvey, 2013; Chesnais, 2010) e que envolviam direta e indiretamente as transformações urbanas das primeiras décadas do século XX. Esses documentos serviam ao propósito de mobilizar a terra na forma mercadoria e, na esfera da circulação do capital, assumiam a forma ${ }^{6}$ social do dinheiro.

Neste artigo, propomos um conjunto de documentos e informações fundamentais para a identificação de práticas financeirizadas ${ }^{7}$ que permeavam a produção das cidades brasileiras nas primeiras décadas dos novecentos. Assim, partimos da cidade da Parahyba para demonstrar que a realização dessas práticas ocorria não apenas nos centros urbanos que centralizavam o capital

2 As promessas da modernidade de que trata José de Souza Martins (2000).

3 Em ambos os casos, renda fundiária e juros, trata-se de uma apropriação da mais-valia total produzida socialmente (Grespan, 2011; Godoy, 2019).

4 Personagem do conto "O empréstimo" escrito originalmente em 1882 e publicado em Papéis avulsos (Machado de Assis, 1994).

5 Que resultaram nas práticas financeirizadas analisadas na tese recém-defendida.

6 "[...] a função da forma é a de revestir de coerência aquilo que é contraditório e tenso. É por isso negação mediadora das relações que expressa" (Martins, 1979, p. 13). O valor encobre todas as relações que o criam e nega suas contradições. Com base em Marx, Godoy (2019) mostra que, na reprodução ampliada do capital, em que a circulação ocorre pelo movimento D-M-D', o valor assume formas particulares: dinheiro e mercadoria. $O$ valor existe primeiro como dinheiro, depois como mercadoria e em seguida novamente como dinheiro. Nesse sentido, dinheiro e mercadoria aparecem apenas como formas de existência particulares do valor em processo ou do capital. Quando o dinheiro se apresenta como valor autonomizado, ele aí se manifesta como capital-dinheiro.

7 Tomando por base a pesquisa de nossa tese de doutoramento, valemo-nos dessa denominação para nos referir às práticas que possibilitam a acumulação de capital fictício. 
acumulado. Outrossim, também se desenvolviam nas cidades marcadas por uma urbanização periférica ${ }^{8}$ (Lucena, 2020).

Para uma leitura diligente das fontes históricas aqui propostas, tomamos as lições benjaminianas acerca da necessária desconfiança e estranhamento de quem reconhece e condena a "escravidão anônima" herdada das "vitórias" e "vencedores" pretéritos, pois, "não há documento de cultura que não seja também documento de barbárie" (Benjamin, 2012, p. 43). E, do mesmo modo, incorporamos as definições de Manguel (2020) sobre o leitor ideal com o intuito de "dissecar o[s] texto[s], tirar a pele, cortar o osso até a medula, seguir cada artéria e cada veia e depois dar vida a um novo ser sensível", mas não como um taxidermista ou um arqueólogo, e sim como alguém que recria, que desloca, que lê nas entrelinhas.

É com essa atenção que realizamos uma leitura das escrituras dos livros notariais do 1 Cartório de Registro de Imóveis da Parahyba e algumas páginas selecionadas de jornais publicado entre as décadas de 1910 e 1930, para discorrer sobre a produção da cidade e a cidade como negócio (Santos, C., 2006; Alvarez, 2015). Aqui, os documentos são entendidos não apenas como fonte dos dados empíricos, mas principalmente como instrumentos da abstração que envolve esses processos de produção e circulação.

O enfoque nas décadas de 1910 a 1930 se justifica pela maior expansão dos negócios de sociedades mutuais, cooperativas e sociedades anônimas que se valiam dos instrumentos financeiros existentes para especular em torno da propriedade imobiliária. Ao mesmo tempo, compreende o período de intensas transformações no espaço urbano da capital parahybana, que, por sua vez, ensejaram a antecipação de valor em torno das obras a ser realizadas, das edificações a ser construídas e das terras então incorporadas à malha urbana da cidade.

Organizado em três seções, o artigo desvela a cidade sob as notas dos jornais, das escrituras dos livros notariais e da forma dinheiro; em seguida, analisa a conformação da cidade como negócio a partir de práticas financeirizadas; e, por fim, discorre sobre o papel dos documentos como instrumentos fundamentais para mobilizar a cidade produzida como mercadoria e ocultar o despojo necessário a sua produção e circulação.

\section{A cidade: entre cartórios, periódicos e "praças comerciais"}

A imagem de um tabuleiro de xadrez com que Carlos Rovaron (2015) trata das transações envolvendo a propriedade imobiliária9 em Caldas-MG no curso dos oitocentos, é bastante ilustrativa das estratégias e sujeitos envolvidos nas operações de compra e venda e de crédito com base na terra-mercadoria. Além dessa imagem, chama atenção o processo denominado formalização legal das transações de terra, que consistiu na criação de formalidades contratuais e nas leis que as determinavam, mas também na reestruturação cartorial do final do século XIX. Com isso, foram criados: os cartórios de registro; as novas atribuições para os cartórios de notas, como por exemplo zelar pela padronização e cumprimento das formalidades necessárias ao registro dos contratos; e, gradualmente se conformaram "restrições legais aos contratos [escrituras] particulares,

8 As expressões urbanização periférica e cidade periférica designam espaços sem capacidade de centralização de capitais e que, portanto, se constituíam como fronteiras de expansão do capital excedente dos centros urbanos que comandavam essa centralização.

9 Referimo-nos à propriedade que inclui terrenos e edificações como bens imóveis. 
obrigando que os negócios fossem cada vez mais controlados pelo Estado por meio da lavratura e registro dos seus contratos em instituições públicas (os cartórios)" (Rovaron, 2015, p. 28-29).

Essas instituições, com suas normas e condutas legais então definidas, criaram um conjunto de instrumentos jurídicos e financeiros para garantir a circulação dos títulos de propriedade, mas, concomitantemente, para impulsionar o mercado de crédito dos quais essas mesmas propriedades deveriam ser o lastro. Buscava-se a centralização e publicidade ${ }^{10}$ das transações que envolviam a propriedade imobiliária com o fito de torná-la a principal garantia das operações creditícias.

Portanto, estavam dadas as condições em que se atrelavam o mercado de terras e o mercado de crédito. Certamente e a despeito da legislação já em vigor a partir dos anos 1860 , as últimas décadas do século XIX ainda constituíam um momento de transição decorrente do fim da escravatura." Mas os dados sobre hipotecas, sobre a fundação de sociedades de crédito predial e sobre os novos negócios em torno da propriedade imobiliária das primeiras décadas dos novecentos revelam como as operações de crédito foram profundamente entrelaçadas àquelas propriedades.

Por sua vez, as escrituras públicas dos livros notariais dos cartórios; os balancetes e negócios anunciados por sociedades de crédito; bem como as apólices e títulos hipotecários gerados por essas transações; serviam como instrumentos que alinhavavam as frações do capital ligadas ao crédito àquelas ligadas ao mercado imobiliário que então se constituía. Assim, as mesmas mãos que anunciavam o "sucesso" desses negócios com a extração de dividendos na forma de renda e juros, transferiam os títulos de um lugar para outro, entre muitas gavetas infestadas de grilos. ${ }^{12}$

Em termos quantitativos, os prédios e as terras urbanas eram os tipos de imóvel que mais circulavam nas páginas, fossem estas escrituradas nos cartórios ou tipografadas na sede das gazetas. Isto porque, esses bens já vinham sendo catalogados, inventariados, registrados, documentados e, por fim, comprados e vendidos, muito antes da legislação hipotecária dos anos 1860 e mesmo antes da Lei de Terras, de $1850 .{ }^{13}$ Obviamente, o processo de formalização legal das transações intensificou a presença das propriedades urbanas nas "praças comerciais", como mostra a pesquisa de Marcondes $(2014,2015)$. É certo que as maiores quantias movimentadas em empréstimos hipotecários seguiam envolvendo os imóveis rurais. Contudo, as questões que ainda envolviam incertezas quanto aos títulos dessas últimas propriedades faziam com que os bens mais "seguros" nas operações de crédito fossem de fato os imóveis urbanos.

As peças desse jogo de xadrez que envolvia os mercados já mencionados, avançaram até o período republicano; e, cercaram novas cidades além dos centros urbanos economicamente mais dinâmicos, em busca de novas frentes de expansão para realização de seus investimentos, de impor novas práticas especulativas e/ou de realizar apropriações i-legais $^{14}$ de toda sorte.

10 "[...] ato de concentrar as informações nos cartórios de registro e torná-las públicas para o mercado" (Rovaron, 2015, p. 34).

11 Cf. J. Schulz (2013) no livro A crise financeira da abolição.

12 Cf. Prieto (2016), Silva, L. (1996) e Oliveira et al. (2020), que discutem a grilagem de terras no Brasil em diferentes momentos históricos da formação territorial nacional, e Brito (2006), para entender esses processos no espaço urbano de São Paulo no início dos novecentos.

13 Cf. Rolnik (1997), Brito (2006), Beatriz Bueno (2018), Glezer (2007) para o caso de São Paulo, Ana Cristina Silva (2005) para o caso de Fortaleza, Ribeiro (1997) para o Rio de Janeiro e Rovaron (2015) para o tratamento da propriedade urbana na legislação.

14 A grafia procura destacar que, no caso do aparato jurídico construído para a política de terras no Brasil ao longo do tempo, a legalidade e a ilegalidade estão imbricadas de tal maneira que é impossível dissociá-las. Elas se relacionam dialeticamente, uma legitimando e contraditoriamente negando a outra. Nesta pesquisa, queremos enfatizar como aquela estrutura legal foi criada e apropriada para legitimar o ilegal. 
Um estudo sobre a cidade da Parahyba que resultou no presente artigo e que teve por base alguns periódicos e as escrituras ${ }^{15}$ das décadas de 1910 a 1930 (Quadros 1 e 2) revela que mesmo nas cidades periféricas do "presente de então" havia práticas financeirizadas cujo lastro eram os bens imobiliários antes mencionados, especialmente os urbanos. Para esse estudo, foram lidas e fichadas 525 escrituras e algumas notícias e anúncios de 15 jornais ${ }^{16}$ diferentes publicados nesse período.

\section{Quadro 1 - Esquema para fichamento das escrituras pesquisadas}

\begin{tabular}{|l|c|l|l|}
\hline \multicolumn{1}{|l|}{ livro N. X - notas de 27 maio a $\mathbf{1 6}$ outubro 1913} \\
\hline $\begin{array}{l}\text { tipo de negociação/ } \\
\text { página do documento }\end{array}$ & $\begin{array}{l}\text { data da } \\
\text { escritura }\end{array}$ & tipo de imóvel/ localização & contratantes \\
\hline $\begin{array}{l}\text { exemplo: } \\
\text { hipoteca/ } \\
\text { p.? }\end{array}$ & $?$ & $\begin{array}{l}\text { exemplo: } \\
\text { Chalet/ } \\
\text { Rua da Independencia }\end{array}$ & $\begin{array}{l}\text { exemplo: } \\
\text { hipotecante: ?/ } \\
\text { hipotecário:? }\end{array}$ \\
\hline
\end{tabular}

organização: A autora.

\section{Quadro 2 - Esquema para fichamento das notas e dos anúncios de jornal}

\begin{tabular}{|c|c|c|l|}
\hline jornal X \\
\hline data de publicaçã & $\begin{array}{l}\text { título da } \\
\text { matéria }\end{array}$ & palavras-chave & $\begin{array}{l}\text { transcrição de trechos* } \\
\text { (se for o caso) }\end{array}$ \\
\hline$?$ & $?$ & $?$ & $?$ \\
\hline
\end{tabular}

organização: A autora.

* No caso das matérias mais longas e que demandam transcrições mais completas, há que abrir um novo documento específico.

A escolha pelas escrituras decorreu do papel que elas cumpriam, qual seja, o de tornar públicas as transações então realizadas e que envolviam propriedades imobiliárias. Ademais, sua existência permitia realizar operações financeiras que resultavam não apenas na obtenção de renda fundiária (a exemplo da compra e da venda), como também no embolso de juros. Entre essas operações, destacavam-se os empréstimos hipotecários, que por sua vez permitiam a criação de instrumentos financeiros como as letras hipotecárias, e a venda condicional, que permitia atrelar ao ato de compra e venda a obtenção de juros em decorrência de condições específicas do contrato, como explicamos a seguir.

As informações coletadas nas escrituras (Quadro 1) mais relevantes para este artigo foram o tipo da negociação registrada, a data de sua realização e o nome dos contratantes. Os dados da localização do imóvel não são mencionados aqui por remeter ao intraurbano, o que foge ao escopo da proposta.

Vale mencionar também que a comparação daquelas informações (tipo de negociação, data do documento e contratantes) permite identificar práticas que não necessariamente tem uma tipologia própria das escrituras e que dizem respeito à especulação em torno da propriedade imobiliária, tal como as que triplicavam o preço de um imóvel de um dia para outro, ou como aquelas relativas à obtenção de crédito, incluindo a criação de instrumentos financeiros.

15 Encontradas no arquivo do Cartório Carlos Ulisses (10 Tabelionato de Notas e Registro Geral de Imóveis na cidade da Parahyba).

16 A União (PB), Revista Era Nova (PB), O Jornal (PB), Gazeta Parahybana (PB), Jornal Pequeno (PE), Jornal do Recife (PE), Diario Pernambucano (PE), A Provincia (PE), O Combate (SP), Illustração Paulista (SP), Correio Paulista (SP), O Paiz (RJ), A Noite (RJ), Correio da Manhã (RJ) (1906-1934). Acervos: Hemeretoca Digital da Biblioteca Nacional, IHGP e Arquivo Privado Maurilio de Almeida. 
Portanto, as práticas financeirizadas compreendidas a partir desses desdobramentos das escrituras tinham íntima relação com uma antecipação de valor com base na cidade ainda por ser produzida. Em outras palavras, a circulação de títulos daqueles instrumentos financeiros na forma social de dinheiro dizia respeito ao processo de abstração da cidade-mercadoria. Isto, o título, fosse a escritura fosse na forma social de dinheiro, apagava: o rastro de apropriações i-legais de terras e prédios; as denúncias e as violências em torno das expulsões de moradores; o despojo que envolvia as demolições que estimulavam a antecipação de valor; e, a lógica de endividamento nas operações creditícias.

Para exemplificar, lembremos o caso da venda em hasta pública de três lotes, de propriedade do governo do estado da Parahyba do Norte, localizados à avenida João Machado, comprados por Vicente Rattacoso (comerciante da empresa Rattacoso E Cia). A venda foi realizada no dia 28 de agosto de 1914 e todos os lotes somaram a quantia de 176 mil réis (176\$000). A questão é que no dia seguinte, 29 de agosto, o mesmo senhor Vicente, compareceu ao cartório para escriturar a venda de dois desses lotes em que cada um estava sendo vendido por 300 mil réis (300\$000)! Ou seja, do dia para a noite, foi realizada uma operação de compra e venda com um ganho de "módicos" $300 \%$ sobre a quantia despendida na compra ao Estado. Não satisfeito, cerca de 12 dias depois, o mesmo Rattacoso permutou o terceiro lote por outro terreno na mesma avenida, o que leva à suspeita de outra operação especulativa.

Além dessa prática, era comum a compra e venda condicional que consistia na transação em que o comprador adquiria jus domínio e direito de posse sobre um imóvel por tempo limitado, em troca de receber o valor pago pelo imóvel acrescido de um percentual de juros (geralmente $2 \%$ ao mês). Por sua vez, o vendedor do imóvel deveria pagar os juros acordados e, ao final do prazo estipulado (comumente definido em 2 ou 3 anos), devolver a quantia recebida na transação, caso contrário, o dito comprador teria a posse definitiva do imóvel, tendo que pagar apenas o imposto de transmissão e demais impostos que porventura tivessem de ser cobrados. Ademais, os empréstimos hipotecários eram frequentes nas escrituras públicas sobre imóveis urbanos.

E a situação em nada diferia de outras cidades maiores e mais dinâmicas economicamente. Lembremos das denúncias publicada no jornal O Combate sobre as "negociatas d'A Previdencia" na cidade de São Paulo, em que relatava o caso de um homem que hipotecou seu imóvel por 15 contos de réis e em questão de horas a dívida foi resgatada, o imóvel foi vendido novamente por 35 contos e em seguida foi novamente hipotecado no valor de 37 contos de réis à sociedade mutual, "A Previdencia". Portanto, pelo que indica o jornal, no mesmo dia estiveram no cartório o primeiro hipotecário, Agenor de Azevedo; o segundo proprietário, o secretário de agricultura, o terceiro proprietário dr. Moretzsohn; e a referida sociedade como hipotecante. Vale dizer que este não foi um caso isolado e que as denúncias dos jornais foram baseadas nas próprias escrituras.

Por sua vez, os jornais da época cumpriam não só o papel de criar uma certa "imaginação geográfica" (Harvey, 2015) em torno do que era a cidade e do que ela poderia "vir a ser" no âmbito da modernidade burguesa, mas também propagandeavam as "vantagens" em torno das negociações atreladas à implantação de infraestruturas e serviços urbanos.

E, além da difusão dessas promessas, os próprios documentos publicados nesses jornais evidenciavam aquelas práticas na forma de balancetes em que se descrevia os "passivos" e "ativos" na forma de empréstimos e letras hipotecárias, bens imóveis, ações, apólices, títulos da dívida pública e contribuições mutuárias. Na Parahyba, o periódico mais emblemático 
(mas não o único) da divulgação dessas inúmeras formas de extrair dividendos e auferir renda e juros era o jornal A União.

Inclusive, esse jornal nos revelou que, no curso da década de 1910 até os primeiros anos da de 1930, atuaram sociedades mutuais e/ou de crédito predial oriundas de vários centros urbanos economicamente importantes como Recife, São Paulo, Rio de Janeiro e cidades menos relevantes para a economia interna, a exemplo de São Luiz do Maranhão. Uma pesquisa complementar em periódicos publicados nessas cidades mostrou que as sociedades que chegaram à capital parahybana ao longo dos anos 1910-30 centralizavam seu capital e seus negócios imobiliários nessas mesmas cidades, mas ao mesmo tempo os expandiam para os núcleos urbanos que passavam por (ou pelo menos anunciavam) transformações urbanas oriundas da instalação de serviços e infraestruturas urbanas. Isso indica que a Parahyba, assim como outras cidades periféricas que igualmente incorporavam o ideário da modernidade na produção de seu espaço urbano, constituía-se como fronteira de expansão para as frações de capital próprias daqueles negócios.

É importante dizer que muitas das obras e serviços "prometidos" nos projetos de modernização da capital parahybana ficavam quase sempre inconclusos ou nem sequer eram executados. Contudo, quer fosse um plano, quer fosse um projeto inacabado, o que interessava era a possibilidade de antecipar o valor a ser produzido na (re)construção da cidade e na sua expansão. Para ilustrar, citamos o caso em que o governo do estado da Parahyba do Norte anunciava um "empréstimo popular" no valor 8 mil contos de réis (8.000:000\$000), dividido em apólices (nominativas e ao portador) que renderiam cada uma 6\% de juros ao ano, que serviria para "custear as despezas com a construcção da rêde de exgotto e melhoramento e ampliação do serviço de abastecimento d' agua da capital do Estado".

O referido anúncio, feito com destaque nas páginas do jornal A União (Figura 1), não só pormenorizava os detalhes das operações financeiras em torno da produção material do espaço urbano, mas também revela como ocorria a criação dos muitos títulos (apólices) que serviam ao processo de conformação da cidade como mercadoria. Afinal, aqueles títulos circulariam nas principais praças comerciais do país - principalmente no Rio de Janeiro -, já que o então delegado do estado, João Pessoa Cavalcanti, e o corretor de fundos públicos Ernesto Stampa, foram ao Rio lançar as apólices referentes a esse empreendimento. Em comunicação oficial, as apólices lançadas na Bolsa do Rio de Janeiro chegaram a valer 98 mil réis. ${ }^{17}$

\section{Figura 1 - Anúncio do "Emprestimo popular" criado para realizar as obras de saneamento e melhoramentos dos serviços de abastecimento de água na cidade da Parahyba}

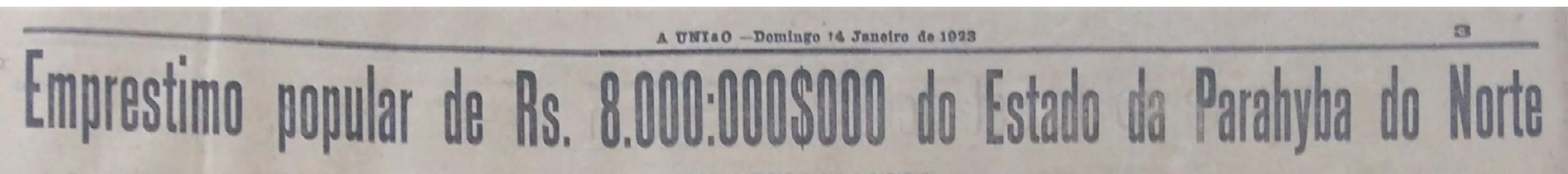

Manifesto para a emissão de uml "Emprestimo Popular", com premios, de Rs. 8.000:000\$000

Dividido em 80.000 apolices, NOMINATIVAS e ao PORTADOR, do valor nominal de Rs. $100 \$ 000$ cada uma, juros de $6 \%$ ao anno, typo $90 \%$, auctorizado pela lei n. 542 , de 23 de novembro de 1921 , art. $30^{\circ}$, n. 11 e nos termos do decreto n. 1157, de 26 de junho do corrrente anno de 1922

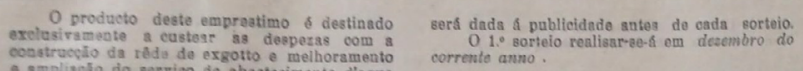

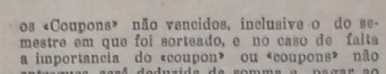


Nesse período, divulgava-se a oportunidade de "muito dinheiro na Parahyba" (Figura 2); a possibilidade de se tornar proprietário de sua própria casa (Figura 3); e, a importância de investir e embolsar juros na modernização da cidade, a exemplo do que mencionamos anteriormente.

\section{Figura 2 - Propaganda da União Mutua (Companhia Constructora e de Credito Popular) anunciando já haver premiado "muito dinheiro na Parahyba"}

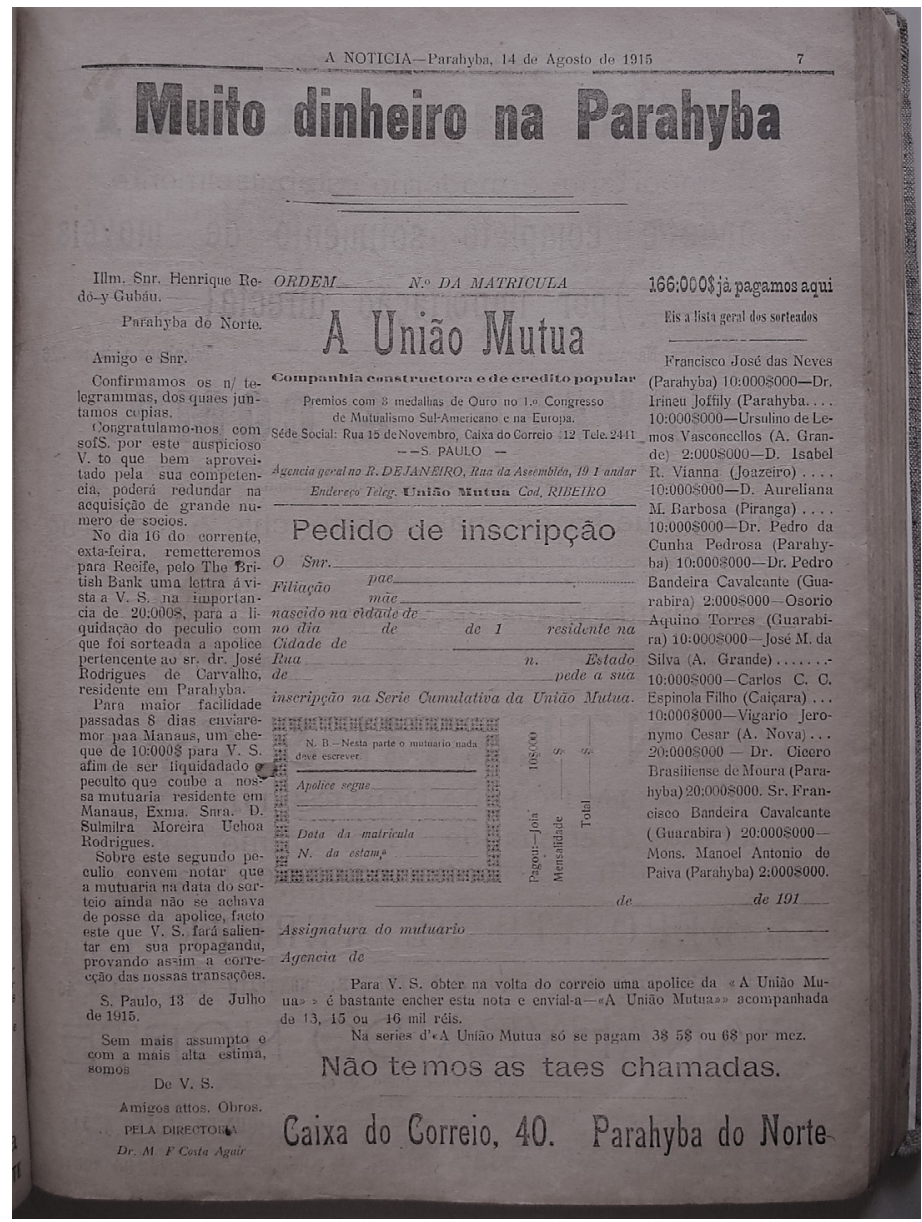

fonte: A Noticia, 14 ago. 1915

acervo: Laboratório de Pesquisa Projeto e Memória, coordenado pela professora Ma Berthilde de B. L. e Moura Filha (PPGAU/UFPB).

As sociedades que ofereciam crédito, incluindo aqui o chamado "crédito predial", como era o caso da União Mutua, induziam à ideia de que o "muito dinheiro" ali acumulado seguiria circulando localmente. Isso porque anunciava a quantia de seus prêmios indicando o número e o nome dos sócios mutuários parahybanos até então sorteados. Porém o que os jornais ocultavam é que, na realidade, esse dinheiro era dos muitos títulos (apólices, letras hipotecárias e diversos outros títulos de dívidas) criados a partir da expectativa em torno da cidade que "viria a ser" moderna.

Ocorria uma verdadeira "transferência geográfica de valor" (Godoy, 2019) para outros centros urbanos quando essa sociedade e outras tantas reuniam as contribuições dos sócios para usá-las na realização de negócios urbanos - como os imobiliários - nas cidades onde ficavam suas sedes (Figura 3).

17 "O emprestimo da Parahyba e a cotação das apolices", A União, 21 jun. 1923; "O emprestimo do Estado e o sorteio de hoje. A cotação das apolices na Bolça do Rio de Janeiro", A União, 23 jun. 1923. 
Aliás, tratava-se de uma transferência geográfica de valor não só por causa das quantias reunidas na Parahyba e transferidas para empreendimentos imobiliários e negócios financeiros em cidades como São Paulo e Rio de Janeiro, mas porque muitos dos sócios mutuários eram proprietários, comerciantes e/ou governantes de cujo capital advinham as atividades que envolviam os projetos de modernização da cidade.

Entre os premiados, estavam figuras públicas como Irineu Joffily, José Rodrigues de Carvalho, Monsenhor Manuel Pinto de Paiva, Francisco José das Neves, Pedro da Cunha Pedrosa e Cicero Brasiliense Moura, entre outros; e os prêmios variavam entre 10 e 20 contos de réis. Em 1915 a União Mutua anunciava, em decorrência de mais uma de suas campanhas propagandistas, a associação de 256 novos sócios parahybanos tendo sido agenciada ora pela figura jurídica da Ribeiro Carvalho E Cia, ora anunciada em nome do próprio Aprigio de Carvalho. Mas, apesar do volume de dinheiro ali distribuído, o que interessava à União Mutua era reunir mais sócios em prol de seus negócios na capital paulista e distribuídos entre mercado hipotecário, mercado imobiliário, mercado de ações e loteamento de terras cuja propriedade era um tanto escusa. Para se ter uma ideia do capital mobilizado nesses negócios, vale mostrar que em dois anos de fundação (entre 1911 e 1913) essa sociedade incorporou um capital realizado (acionista) de 1 mil contos de réis (1.000:000\$000), distribuído em 10 mil ações, e um capital mutuário subscrito de 25 mil contos. Além disso, até 1913 a União Mutua tinha empregado pelo menos 3 mil contos (3.000:000\$000) em construções de casas em Santos, Minas Gerais e São Paulo (Lloyd et al., 2013).

\section{Figura 3 - Propaganda d'A Mutua Predial do Recife (Sociedade Anonyma de Construcções e Premios) anunciando seu capital e os valores das mensalidades para os mutuários}

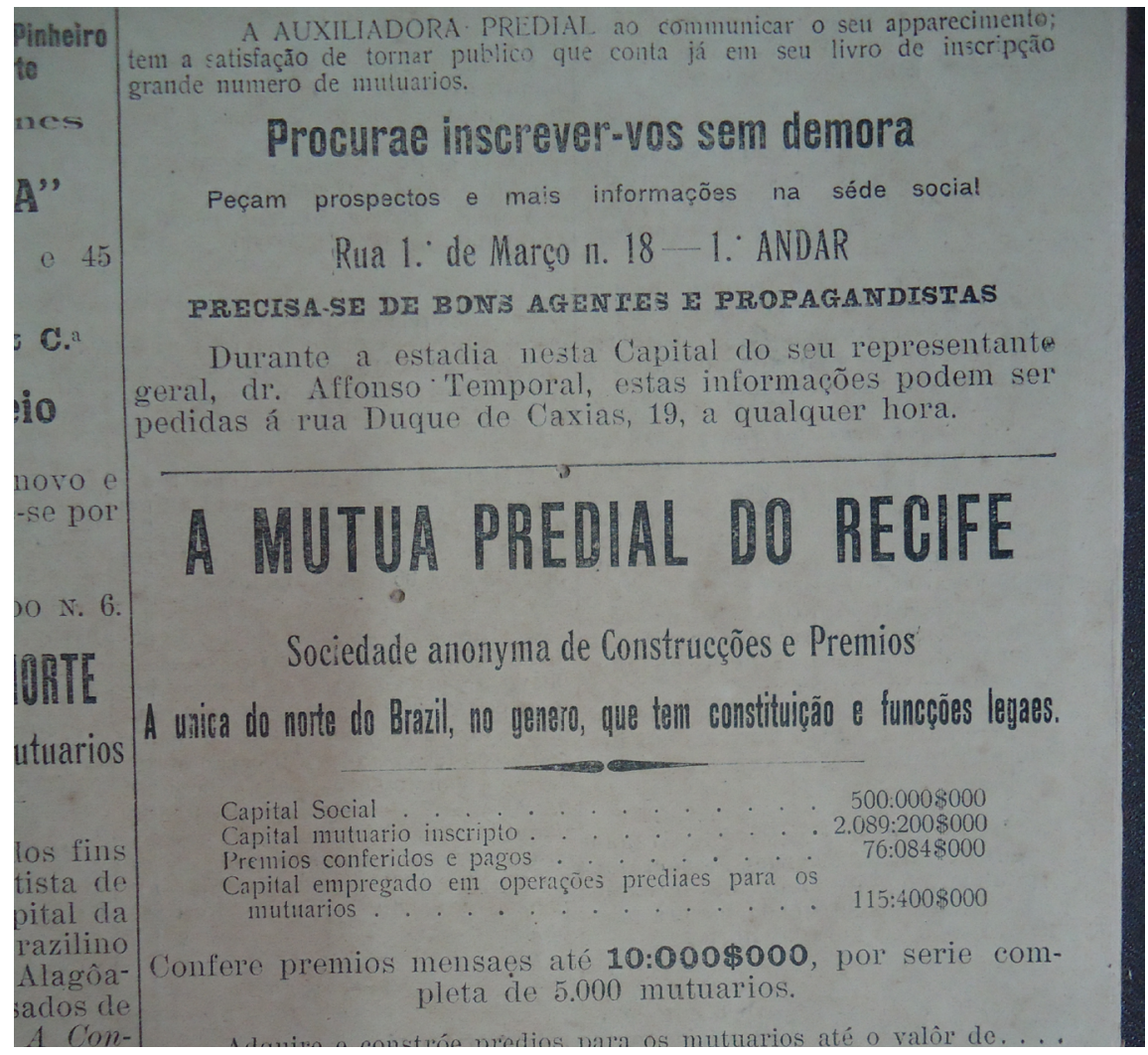

fonte: A União, 10 dez. 1913

acervo: Hemeroteca do Instituto Histórico e Geográfico da Paraiba (IHGP). 
fato é que uma cidade periférica como a Parahyba incorporava cada vez mais, nas práticas que produziam seu espaço urbano, uma lógica que atrelava a propriedade imobiliária às operações creditícias e especulativas. É certo que, em termos quantitativos, não se comparava aos negócios realizados em São Paulo ou no Rio de Janeiro. Mas, de todo modo, os documentos anunciavam a Parahyba como uma nova fronteira de expansão das frações de capital envolvidas nos processos ora descritos. A cidade aparecia na então chamada "praça comercial" parahybana, produzida como mercadoria, ou seja, desvencilhada dos processos de violência que a constituíam, destituída do trabalho concreto que a produzia materialmente, fragmentada e parcelada nos moldes da abstração própria do capital. Essa cidade foi inserida na esfera da circulação sob as notas dos livros cartoriais que escrituravam as operações de compra e venda, as hipotecas e as letras hipotecárias então criadas. Essa mobilização do imóvel era, por sua vez, estampada e algumas vezes denunciada nas notas dos jornais então veiculados.

Para desvendar esses processos, há que verificar não apenas o conteúdo formal dos documentos, como datas e sequências das publicações e registros, os nomes citados, os materiais descritos e os dados listados, mas principalmente o que os documentos não dizem, o que eles realmente eram (e ainda são). Após dissecá-los, a leitura pode dar vida a um "novo ser sensível", para lembrar das lições de Alberto Manguel, ou pode ressuscitar os mortos antes celebrados, como alerta Walter Benjamin (2012).

\section{A mobilização do imóvel e a "derrama de dinheiro"}

Na coluna "Interesses da Parahyba", regularmente publicada no jornal A União, um texto de autoria desconhecida chamava a atenção dos leitores para notarem:

[...] os melhoramentos públicos adstrictos ás nossas fontes economicas, taes como as estradas de rodagem e linhas telegrapficas, que est[avam] sendo construidas não só para amenizar a situação dos flagellados da sêcca como também para corresponder aos esforços empregados pelo sr. senador Epitacio Pessôa no sentido de acautelar os interesses da nossa terra (A União, 29 jan. 1916, grifo nosso).

Na mesma tônica e comentando as obras da década de 1930, especialmente as linhas férreas e as obras de açudagem, Celso Mariz (1978[1939]) mencionou a importância da "derrama de dinheiro" decorrente desses empreendimentos, mesmo nos casos daqueles que não foram concluídos, para "sanear" o ambiente das praças parahybanas. Em suas palavras:

$\bigcirc$ trabalho dos grandes açudes e da estrada de ferro que cortaria o Estado visando ligar Cajazeiras a Campina, foi suspenso no governo seguinte [governo de Gratuliano da Costa Brito, 1932-1934]. Rescindidos os contratos com os americanos, pelos quais o presidente Epitácio quisera segurar o prosseguimento dos serviços até o fim. De qualquer maneira, o movimento, o acervo de obras 
e maquinismos e fundações que ficaram, as vias que passaram a facilitar a circulação do comércio, concorreram como fatores maiores para uma etapa nova na vida do Estado. A derrama de dinheiro saneou logo o ambiente das praças (Mariz, 1978[1939], p. 52, grifo nosso).

Na realidade, essas palavras explicitam que os inúmeros créditos aprovados e efetivados por parte da União para a instalação daquelas infraestruturas e o trabalho ali realizado serviam principalmente para aumentar a circulação de dinheiro no comércio parahybano e "acautelar os interesses" locais. Trata-se da "idéia popular de quem guarda dinheiro no colchão e [acha que] ele perde valor [que] é própria de uma percepção popular de que o dinheiro no capitalismo tem que se manter no mercado, circulando" (Damiani, 2005, p. 62).

E, mesmo com essa percepção, escapa à análise de Celso Mariz o fato de que a "derrama de dinheiro" não advinha apenas do erário. Há que lembrar que os interesses "da terra", ou seja, do capital mercantil local, também se voltava para os títulos e ações emitidos em torno desses negócios. Ademais, concomitantemente às obras portuárias, ferroviárias e de açudagem realizadas no território parahybano, ocorriam também as inúmeras obras de modernização da capital do estado.

A cidade, parcelada e estilhaçada em inúmeros títulos da dívida pública, letras hipotecárias, escrituras de venda condicional e de hipotecas, apólices nominativas e ao portador, era mobilizada na forma social do dinheiro ou, para dizer na linguagem contábil dos negociantes, ativos circulantes. Afinal, essa substituição se fazia necessária em uma sociedade que se pretendia moderna, mas que ainda carecia de numerário disponível nas "praças". Isso porque, a emissão de títulos se apresentava como solução para o momento histórico pós-crise do encilhamento, no qual se observava uma certa instabilidade financeira, bem como as restrições do padrão-ouro sobre a política monetária e creditícia. Assim, adaptando-se aos diferentes e novos arranjos institucionais e econômicos do início dos novecentos, as companhias brasileiras combinaram formas diversas de financiamentos por meio de emissões de ações e títulos (Musacchio, $2009^{18}$ apud Marcondes, 2014). Nesse contexto, o mercado de crédito privado envolvendo as propriedades urbanas cresceu bastante (Marcondes, 2014, 2015).

Naquele momento, vários agentes das sociedades que ofereciam prêmios em dinheiro e crédito predial viajaram pelo Brasil instalando agências locais ou buscando empresas que cumprissem esse papel, com o fito de angariar sócios mutuários. Na Parahyba, chegaram sociedades principalmente da capital federal, de São Paulo e de Recife (Quadro 3). Mas, também foram fundadas sociedades locais. Em geral, anunciava-se nos jornais a possibilidade de prêmios em dinheiro, pensões vitalícias e o então chamado "crédito predial".

$18 \mathrm{MUSACCHIO}$, A. Experiments in financial democracy: corporate governance and financial development in Brazil, 1882-1950. New York: Cambridge University Press, 2009. 


\section{Quadro 3 - Sociedades mutuais anunciadas na cidade da Parahyba nas décadas de 1910-30}

\begin{tabular}{|c|c|c|}
\hline \multicolumn{3}{|c|}{ Sociedades mutuais propagandeadas na cidade da Parahyba $-1910-30$} \\
\hline sociedade, cooperativa ou montepio & $\begin{array}{l}\text { ano da } \\
\text { fundação }\end{array}$ & $\begin{array}{l}\text { ano(s) da propaganda } \\
\text { e/ou da atuação na } \\
\text { cidade da Parahyba }\end{array}$ \\
\hline Montepio dos Funccionarios do Estado da Parahyba (PB) & 1913 & $1913-1970^{19}$ \\
\hline Cooperativa Predial Parahybana (PB) & 1912 & $1912-1913$ \\
\hline A Previdente (PB) & 1902 & 1906-1931 \\
\hline Caixa Mutua de Pensões Vitalicias (SP) & 1903 & 1910 \\
\hline A Previdencia - Caixa Paulista de Pensões (SP) & 1906 & 1910-1915 \\
\hline Economisadora (SP) & 1907 & $1910-1915$ \\
\hline $\begin{array}{l}\text { A União Mutua } \\
\text { (companhia Constructora e de Crédito Popular) }\end{array}$ & 1911 & $1912-1918$ \\
\hline $\begin{array}{l}\text { Credito Predial de São Paulo - Sociedade Cooperativa } \\
\text { Constructora e de pecúlios por sorteios (SP) }\end{array}$ & 1907 & 1913 \\
\hline Auxiliadora Predial S. A. (SP) & $\begin{array}{c}\text { pelo menos } \\
1933^{(* *)}\end{array}$ & $1934-1935$ \\
\hline Emprêsa Líder de Construções (SP) & $?(*)$ & 1934-1935 \\
\hline Empresa Constructora Universal Ltda (SP) & $\begin{array}{c}\text { pelo menos } \\
1917^{(* *)}\end{array}$ & 1934-1935 \\
\hline $\begin{array}{l}\text { Vitalícia Pernambucana - Sociedade Mutua de Pensões } \\
\text { e Peculios (PE) }\end{array}$ & 1909 & 1910-1915 \\
\hline Mutualidade Pernambucana - Sociedade de Seguros de Vida (PE) & 1912 & 1913 \\
\hline Auxiliadora Predial (PE) & 1913 & 1913 \\
\hline $\begin{array}{l}\text { Mutua Predial do Recife - Sociedade Anonyma de Construcções e } \\
\text { Premios (PE) }\end{array}$ & 1912 & 1913 \\
\hline $\begin{array}{l}\text { Garantia Predial do Norte - Sociedade Mutua de Construções e } \\
\text { Peculios(PE) }\end{array}$ & 1913 & 1913 \\
\hline $\begin{array}{l}\text { Credito Mutuo Predial - Sociedade Anonyma de Peculios } \\
\text { Prediaes (MA) }\end{array}$ & 1914 & 1923-1934 \\
\hline A Equitativa (RJ) & 1896 & 1906-1923 \\
\hline Companhia Imobiliaria Kosmos (RJ) & $\begin{array}{c}\text { pelo menos } \\
1928^{(* *)}\end{array}$ & $1934-1935$ \\
\hline A Promotora da Casa Própria (RS) & \begin{tabular}{c|} 
pelo menos \\
$1932^{(* *)}$
\end{tabular} & 1934-1935 \\
\hline Sociedade Anonyma A Predial (PR) & $\begin{array}{c}\text { pelo menos } \\
1922^{(* *)}\end{array}$ & 1926 \\
\hline
\end{tabular}

fonte: A União (PB); Revista Era Nova (PB); O Jornal (PB); Gazeta Parahybana (PB); Jornal Pequeno (PE); Jornal do Recife (PE); Diario Pernambucano (PE); A Provincia (PE); O combate (SP); Illustração Paulista (SP); Correio Paulista (SP); O Paiz (RJ); A Noite (RJ); Correio da Manhã (RJ) (1906-1934).

acervos: Hemeretoca Digital da Biblioteca Nacional e Arquivo Privado Maurílio de Almeida. organização dos dados: A autora, 2020

(*) Não conseguimos identificar a informação na pesquisa documental.

(**) Encontramos apenas o ano aproximado.

19 Em 1970, o montepio passou a se chamar Instituto de Previdência do Estado da Paraiba (Ipep). 
Todas essas sociedades buscavam se apropriar do valor excedente produzido com as transformações urbanas realizadas ou do valor antecipado com a projeção de novos serviços para a modernização da cidade. Assim, enquanto a cidade não era efetivamente saneada com a implantação do sistema de esgoto, saneava-se a "praça" comercial parahybana e de outros centros urbanos com a circulação do espaço-mercadoria na forma de ativos de valor. Nesse processo, os terrenos e imóveis urbanos (públicos e privados), as obras e projetos de infraestruturas e serviços urbanos e mesmo a expectativa da cidade moderna ainda "por vir", enfim, todos os bens imóveis eram mobilizados em prol da "derrama de dinheiro".

Sobre esse processo de mobilização do imóvel como mercadoria, encontramos um anúncio bastante ilustrativo da lógica e das estratégias de consolidação desse processo. A propaganda se encontrava no jornal A União em nome da Auxiliadora Predial S.A, sediada em São Paulo. A Figura 4 retrata um homem que, detendo uma ampulheta, representa o tempo que "apresenta provas concretas" de que o problema do aluguel seria resolvido na cidade a partir de um "fundo de cooperação". A casa própria, por sua vez, era prova "concreta" garantida pelo tempo de acumulação das cifras estampadas em letras garrafais no anúncio.

\section{Figura 4 - Anúncio da Auxiliadora Predial S. A publicado em 1934 na capital paraibana}

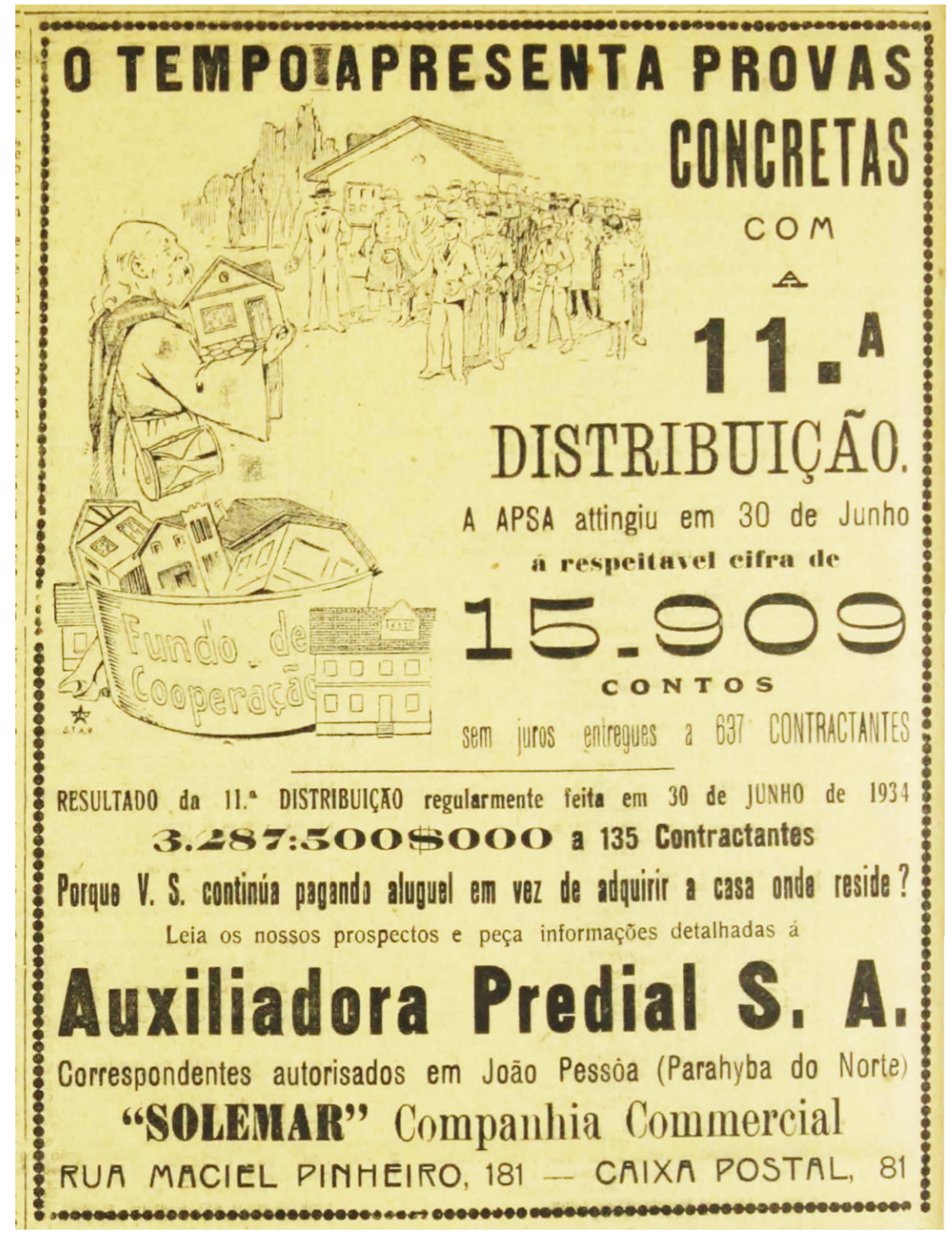

fonte: A União, 1934.

acervo: Arquivo Digital d'A União (https://auniao.pb.gov.br/servicos/arquivo-digital/jornal-auniao). 
No entanto, a construção e disponibilidade dessas casas não se efetivava na prática, ou pelo menos não na proporção esperada. Os entraves referentes às terras ainda por serem apropriadas e as questões relativas ao setor construtivo freavam o que alguns parahybanos pretendiam que fosse "a festa dos tectos". ${ }^{20}$ Portanto, o tempo da produção não era o mesmo da circulação. E como no processo de acumulação do capital, essa circulação se faz mais urgente, as contribuições mensais no âmbito de fundos de cooperação, sociedades mutuais ou negócios desse tipo se apresentavam como solução para acelerar a mobilização de mercadorias que sequer tinham sido produzidas.

Esses negócios realizados ao longo das décadas de 1910-30 muito se anteciparam à afirmação de Francisco D’ Auria, na primeira Jornada da Habitação ocorrida em São Paulo em 1942, quando propôs que:

Quem não possue recursos para adquirir casa própria, mas que tem boa disposição de vontade e método de vida, tem o direito de ser aquinhoado com recursos provindos da economia popular. A economia popular opera o milagre de "fazer montanhas com grãos de areia" (D’Auria, 1942, p. 102).

A emissão de toda sorte de títulos (hipotecários, de ações, da dívida pública) contribuía, portanto, não apenas para atender a demanda de circulante, mas, principalmente, para superar as contingências dadas na esfera da produção, ou seja, para operar o "milagre" de que falava D' Auria.

sistema de crédito emerge, portanto, como a solução para essa superação, pois, é mediante a expansão desse sistema e por meio dele que o tempo de circulação das mercadorias se torna "tempo de circulação socialmente necessário" (Godoy, 2019, p. p. 53, grifo nosso). As contingências dadas na produção da cidade, ainda mais da cidade periférica, seriam então superadas com a aceleração de sua circulação como mercadoria. Na ordem de prioridades, vinham primeiro os empréstimos, depois (talvez) os imóveis; primeiro as apólices, depois (talvez) os esgotos e o abastecimento de água.

\section{Os títulos: do desembaraço à valorização do espaço}

Quando lançados na esfera da circulação, os títulos de propriedades imobiliárias, de dívidas, de ações e outros que transitavam no âmbito do mercado imobiliário e de crédito aqui evidenciados, não eram meras folhas de papel. Esses documentos, que hoje se apresentam como fontes históricas em muitas instituições de memória, instrumentalizavam e expressavam o processo de abstração dos conteúdos vividos (Silva, A., 2005), ou seja, do trabalho concreto tornado trabalho abstrato. Isso porque a renda fundiária e os juros auferidos com a emissão daqueles títulos consistiam em nada mais que uma fração da mais-valia total produzida socialmente. Portanto, eles revelavam as "determinações da forma [valor] em relação a estes ditos conteúdos" (Silva, A., 2005, p. 42).

Em outras palavras, tudo que era inventariado, assim como escriturado e posto em balanços financeiros era, em realidade, colocado em sua forma valor, o que evidenciava uma sociabilidade estreitamente relacionada "com as determinações do dinheiro" (Silva, A., 2005, p. 42). Exatamente por isso, os títulos apagavam qualquer rastro de grilagem, de violência, de troca de favores clientelistas, 
enfim, de qualquer vestígio que denunciasse o despojo necessário à acumulação da propriedade imobiliária, bem como da riqueza ali acumulada. Cumpriam, portanto, a função de "desemb-raçar" a propriedade de qualquer conflito com terceiros - como constava nas escrituras de compra e venda -, tal como o fetiche da mercadoria fazia com o trabalho nela contido.

Nessa perspectiva, Raymond Williams (2011) nos lembra que no longo processo de saques, conquistas, roubos, intrigas políticas, favoritismo, extorsão e poder do dinheiro, pouquíssimos títulos de propriedade se revelariam livres de mácula. $\bigcirc$ autor afirma que é uma ilusão profunda acreditar na inocência desses documentos. Da mesma forma, há que pensar os balancetes, as cifras, as prestações, os percentuais e as "contribuições" mensais propagandeadas nos jornais do período, porque também compunham o processo de abstração discutido aqui.

fato é que tudo isso envolvia um conjunto de instrumentos financeiros, criado pelo aparato jurídico e institucional de então, que tornava exequível a produção material da cidade e, pari passu, sua comercialização como mercadoria. Sobre isso, há o caso emblemático dos irmãos Péreire que, na França dos anos 1850, agiram baseados em "um misto de intervenções governamentais diretas, criação de crédito e reforma das estruturas financeiras” (Harvey, 2015, p. 162-163). Inclusive, o processo foi seguido por muitas cidades de países europeus (Capel, 2013) e, em alguns casos, na América Latina como na Argentina (Gómez; Correa, 2013; Gómez, 2014).

Sobre o assunto, Paulo Godoy (2019, p. 53), afirma que "[...] o sistema de crédito acelera virtualmente a circulação do espaço-mercadoria e desempenha uma função essencial em seu processo de valorização", pois faz com que "frações do espaço de produção e reprodução social do capital sejam travestidas de um caráter fictício e com projeções de ganhos futuros, isto é, o espaço-mercadoria pode tornar-se também uma espécie de capital fictício". Em outras palavras, trata-se de compreender como a cidade era vendida aos pedaços e, mais que isso, como parte da renda auferida se metamorfoseava em juros e em capital fictício.

A questão é que com a expansão do sistema de crédito o tempo de circulação das mercadorias é reduzido e seus custos também o são. No caso da propriedade imobiliária, parte da renda da terra é apropriada como juros e, no limite, parte de um valor ainda por ser produzido também é apropriado como juros. Tudo isso visava acelerar o tempo de circulação socialmente necessário à realização do valor.

A criação de instrumentos financeiros, baseados em títulos de bens imóveis, constituíam um "momento particular" dos negócios então realizados no processo de produção e valorização do espaço. Para isso, trazemos Ana Silva (2005, p. 21), que, comentando sua pesquisa sobre a cidade de Fortaleza, afirma: "[...] a compreensão dos vários momentos do processo de urbanização não pôde ser realizada [...] sem considerar momentos particulares de realização dos negócios" em que as coisas, técnicas etc. são tomadas como meras mercadorias. Na superfície desse movimento aparecem os agentes, as classes sociais e as frações do capital em disputa, bem como o Estado como um agente mediador.

Na mesma perspectiva, Ribeiro (1997) sugere o reconhecimento dos mecanismos de valorização dos diversos capitais envolvidos na produção e circulação de moradias como sendo parte significativa dos negócios urbanos que então se constituíam. Trata-se, portanto, de discorrer sobre a distribuição e a apropriação de uma parte da mais-valia extraída na e pela produção da cidade, bem como sobre a antecipação de valor viabilizada pela própria cidade produzida. 
Os documentos de que tratamos neste artigo instrumentalizavam esses mecanismos de valorização e, no limite, criavam a ficção própria do dinheiro creditício. A questão é que, nos momentos de crise do capital, esse caráter fictício vinha (vem) à tona. Quanto ao capital acumulado dessa forma, François Chesnais (2010, p. 99-100) faz a seguinte síntese:

Esse termo [capital fictício] designa os títulos que foram emitidos no momento dos empréstimos em dinheiro a entidades públicas ou a empresas ou como expressão da participação dos primeiros participantes no financiamento do capital de uma empresa. Para seus detentores, esses títulos, ações e obrigações, representam um "capital" do qual elesesperam um rendimento regular sob a forma de jurose dividendos (uma "capitalização") e que eles desejam poder vender em um espaço de tempo muito curto, seja em caso de necessidade e de dinheiro, seja para o aplicar de maneira ainda mais rentável. Entretanto, no momento em que eles são vistos sob o ângulo do movimento do capital entendido como capital produtivo de valor e de mais-valia, esses títulos não são capital. No melhor dos casos, são a "lembrança" de um investimento feito há muito tempo. No momento de crashs e outras crises de mercado financeiro, esse caráter fictício dos títulos se revela e se desvaloriza às custas de seus detentores. Mas anteriormente esses títulos podem ter servido de fundamento a operações que somente fizeram a ficção ampliar. Eles puderam ser contabilizados como ativo no balanço dos bancos, utilizados por uma empresa como meio para "pagar" a compra de uma outra no quadro de uma fusão, ou no caso de particulares, colocados como caução para fim de empréstimos.

Essa síntese, demonstra que os inúmeros títulos de dívidas que servem ao processo de valorização das propriedades imobiliárias e de antecipação de valor referente à produção da cidade, só podem ser considerados meras e "inocentes" folhas de papel em momentos de crise de capital, pois perdem completamente o poder de continuar impulsionando o processo de valorização. E é exatamente nesse momento que emergem todas as evidências do despojo necessário à produção da cidade como mercadoria e como negócio; e que esses documentos ocultam. Elas emergem por conta da intensificação dos problemas sociais e das contradições desses processos.

De resto, vale mencionar o papel que o Estado assume, qual seja, o de "socorrer" as diferentes frações do capital e aplacar os ânimos sociais. Talvez tenha sido por isso que, no curso dos anos 1920, quando os agentes das sociedades mutuais diminuíram suas investidas na cidade da Parahyba, que o Estado tenha: impulsionado o Montepio dos Funccionarios do Estado da Parahyba a atuar no mercado imobiliário e hipotecário do período, promovido uma ampla apropriação privada das terras públicas na capital parahybana e subscrito ações e depois encampado o Banco da Parahyba fundado nesses mesmos anos, entre outras ações.

\section{Considerações finais ou sobre uma leitura da cidade de outrora}

Se tomamos a cidade como um palimpsesto que acumula diferentes tempos (não só cronológicos, mas também da acumulação do capital - que implica o tempo da produção e o tempo da circulação), então o desafio de interpretar essa cidade constantemente 
reescrita se imputa a seus leitores. Contudo, para lembrar uma última vez as lições manguelianas apresentadas anteriormente, é preciso pensar não só na definição de um "leitor ideal", mas também na leitura "como ato fundador", um ato criador de um "novo ser sensível". Assim, indicamos possibilidades de leitura não da cidade já escrita, mas da cidade do "por vir" moderno que impulsionava práticas financeirizadas, de antecipação do valor, instrumentalizadas pelos documentos aqui discutidos e analisados.

Neste artigo, focalizamos os diferentes tempos que se avolumavam na produção e na circulação e, portanto, na valorização do espaço urbano da cidade da Parahyba nas primeiras décadas dos novecentos. No entanto, buscamos uma análise que vai além da cidade fixada pelo urbanismo e pela estética arquitetônica da modernidade burguesa de então. Reivindicamos uma leitura da cidade tornada ativo de valor por meio de títulos de propriedade, hipotecas, letras hipotecárias ou de ações etc. que se desdobravam das escrituras públicas de propriedades. Além disso, trazemos à tona o "charme" nada discreto da burguesia que estampava a cidade como negócio nas páginas dos jornais.

Com isso, propomos uma abordagem que trate os documentos não apenas como fontes de dados empíricos, mas que os denuncie como instrumentos do processo de abstração do trabalho concreto que produz a cidade e do despojo que envolve as práticas de antecipação do valor na valorização do espaço. Essa análise permite desvendar práticas financeirizadas na cidade de outrora e demonstra, portanto, o gérmen de processos tão atuais como o de financeirização da cidade.

Jornais, escrituras públicas, balancetes e seus "ativos" e "passivos", cifras e um sem-número de papéis produzidos como meio circulante constituíam as "provas concretas" ${ }^{21}$ desses processos. Os títulos das notícias e também os das propriedades e das negociatas de então propunham a seus leitores uma cidade-texto livre de toda e qualquer contradição. Retomemo-los, portanto, para uma leitura a contrapelo.

\section{Referências}

ALVAREZ, I. A. P. A produção e reprodução da cidade como negócio e segregação. In: CARLOS, A. F. A; VOLOCHKO, D.; AlVAREZ, I. A. P. (Org.). A cidade como negócio. São Paulo: Contexto, 2015. p. 65-79.

BENJAMIN, W. Sobre o conceito de história. In: BENJAMIN, W. O anjo da história. Org. e trad. Belo Horizonte: Autêntica, 2012. p. 7-20; 123-164.

BRITO, M. S. Modernização e tradição: urbanização, propriedade da terra e crédito hipotecário em São Paulo na segunda metade do século XIX. Tese (Doutorado em Geografia) - Faculdade de Filosofia, Letras e Ciências Humanas, Universidade de São Paulo, São Paulo, 2006.

BUENO, B. P. S. A cidade como negócio: mercado imobiliário rentista, projetos e processos de produção do Centro Velho de São Paulo do século XIX à Lei do Inquilinato (1809-1942).

21 Referência ao anuncio da Auxiliadora Predial S.A. (Figura 4). 
Tese (Livre-docência em Arquitetura e Urbanismo) - Faculdade de Arquitetura e Urbanismo, Universidade de São Paulo, São Paulo, 2018.

CAPEL, H. La morfología de las ciudades. Barcelona: Serbal, 2013. v. III: Agentes urbanos e mercado inmobiliario.

CHESNAIS, F. A proeminência da finança no seio do "capital em geral", o capital fictício e o movimento contemporâneo de mundialização do capital. In: BRUNHOFF, S.; CHESNAIS, F; DUMÉNIL, G.; LÉVY, D.; HUSSON, M. A finança capitalista. Trad. Rosa Maria Marques e Paulo Nakatani. São Paulo: Alameda, 2010. p. 95-182.

D' AURIA, F. Jornada da Habitação Economica. Revista do Arquivo Municipal (Jornada da Habitação Econômica), São Paulo, v. 83, n. 7, p. 101-110, 1942.

DAMIANI, A. A geografia que desejamos. Boletim Paulista de Geografia, São Paulo, n. 83, p. 58-90, 2005. Disponível em: http://www.agb.org.br/publicacoes/index.php/ boletim-paulista/article/view/762/643. Acesso em: 12 jun. 2019.

GLEZER, R. Chão de terra e outros ensaios sobre São Paulo. São Paulo: Alameda, 2007.

GODOY, P. R. T. A valorização capitalista do espaço sob a perspectiva da teoria marxista do valor. Relatório de Pós-doutorado em Geografia Humana - Faculdade de Filosofia, Letras e Ciências Humanas, Universidade de São Paulo, São Paulo, 2019. No prelo.

GÓMEZ, J. L. La unión hace la fuerza: las compañías de crédito recíproco y el financiamento hipotecario urbano a bajo interés en argentina entre 1936 y 1955. História Econômica E História de Empresas, v. 17, n. 2, p. 443-473, 2014. doi: https://doi.org/10.29182/ hehe.v17i2.339.

GÓMEZ, J. L.; CORREA, F. R. C. Em torno das origens do financiamento imobiliário no Brasil e na Argentina na primeira metade do século XX: as experiências da companhia Finca e da Associação Predial de Santos. In: CONGRESSO BRASILEIRO DE HISTÓRIA ECONÔMICA, 10., e CONFERÊNCIA INTERNACIONAL DE HISTÓRIA DE EMPRESAS, 10., 2013, Juiz de Fora. Anais... Juiz de Fora, 2013. Disponível em: www.abphe.org.br/arquivos/juan-lucas-gomez_fabio-rogeriocassimiro-correa.pdf. Acesso em: 13 maio 2019.

GRESPAN, J. As formas da mais-valia: concorrência e distribuição no Livro III. Crítica Marxista, Campinas, n. 33, p. 9-30, 2011.

HARVEY, D. Paris: capital da modernidade. Trad. João Alexandre Peschanski. São Paulo: Boitempo, 2015.

HARVEY, D. Os limites do capital. Trad. Magda Lopes. São Paulo: Boitempo, 2013.

LLOYD, R.; FELDWICK, W.; DELANEY, L. T. ; EULALIO, J.; WRIGHT, A. (Org.). Impressões do Brazil no século XX. Londres: Lloyd’s Greater Britain, 1913. 
Disponível em: http://www.novomilenio.inf.br/santos/h0300g39c.htm. Acesso em: 12 out. 2019.

LUCENA, W. G. O crédito predial e a imobilização do imóvel: modernização, mercado imobiliário e associação de capitais na/da Cidade da Parahyba (1910-1930). Tese (Doutorado em Geografia) - Universidade Federal da Paraíba, João Pessoa, 2020.

MACHADO DE ASSIS, J. M. O empréstimo. In: MACHADO DE ASSIS, J. M. Obra Completa. Rio de Janeiro: Nova Aguilar, 1994. v. II: Papéis Avulsos.

MAIA, D. S. A cidade em transformação: primeiros sintomas da modernidade urbana no século XIX. In: MOURA FILHA, M. B.; COTRIM, M.; CAVALCANTI FILHO, I. (Org.). Entre o rio e o mar. João Pessoa: Ed. UFPB, 2016. v. 2. p. 90-112.

MAIA, D. S. As habitações da cidade da Parahyba. In: CARDOSO, C. A. A.; KULESKA, W. A. (Org.). A escola e a igreja nas ruas da cidade. João Pessoa: Ed. UFPB, 2010. p.105-126.

MAIA, D. S. Uma cidade em (re)construção: a cidade da Parahyba no século XIX. Scripta Nova, v. 10, n. 218, ago. 2006. Disponível em: http://www.ub.edu/geocrit/sn/sn-218-38.htm. Acesso em: 12 jun. 2019.

MANGUEL, A. Notas para uma definição do leitor ideal. Trad. Rubia Goldini e Sérgio Molina. São Paulo: Ed. Sesc, 2020.

MARCONDES, R. L. Quem eram os credores? Hipotecários, deppositantes e capitalistas paulistanos (1865-1930). In: CONGRESSO DE HISTÓRIA ECONÔMICA, 11., 2015, Vitória. Anais... Vitória: UFES, 2015.

MARCONDES, R. L. Crédito privado antes da grande depressão do século XX: o mercado hipotecário. Estudos Econômicos, São Paulo, v. 44, n. 4, p. 749-786, 2014. doi: http://dx.doi.org/10.1590/S0101-41612014000400004.

MARIZ, C. Evolução econômica da Paraíba. João Pessoa: A União, 1978[1939].

MARTINS, J. S. As hesitações do moderno e as contradições da modernidade no Brasil. In: MARTINS, J. S. A sociabilidade do homem simples. São Paulo: Hucitec, 2000. p. 17-55.

MARTINS, J. S. O cativeiro da terra. São Paulo: Ciências Humanas, 1979.

OLIVEIRA, A. U. et al. (Org.). A grilagem de terras na formação territorial brasileira. São Paulo: FFLCH, 2020. doi: https://doi.org/10.11606/9786587621326.

PRIETO, G. F. T. Rentismo à brasileira, uma via de desenvolvimento capitalista: grilagem, produção do capital e formação da propriedade privada da terra. Versão Corrigida. Tese (Doutorado em Geografia Humana) - Faculdade de Filosofia, Letras e Ciências Humanas, Universidade de São Paulo, São Paulo, 2016.

RIBEIRO, L. C. Q. Dos cortiços aos condomínios fechados. Rio de Janeiro: Civilização Brasileira, 1997. 
RODRIGUES, A. M. A propriedade da terra como um elemento da desigualdade territorial nas cidades brasileiras. In: JACINTO, R. (Org.). Novas fronteiras, outros diálogos: cooperação e desenvolvimento territorial. Lisboa: Âncora, 2019. v. 36. p. 195-206.

ROLNIK, R. Mercados: legislação urbana e valorização imobiliária. In: ROLNIK, R. A cidade e a lei: legislação, política urbana e territórios na cidade de São Paulo. São Paulo: Studio Nobel, 1997. p. 101-144.

ROLNIK, R. O que é a cidade. 1. reimpr. São Paulo: Brasiliense, 1995.

ROVARON, C. E. O xadrez imobiliário: as peças humanas, o tabuleiro de terras e as novas regras do jogo em Caldas-MG (séc. XIX). Tese (Doutorado em História Econômica) - Faculdade de Filosofia, Letras e Ciências Humanas, Universidade de São Paulo, São Paulo, 2015.

SÁ, N. L. R. A. Do higienismo ao sanitarismo: alterações do espaço urbano da cidade da Parahyba entre 1912 e 1927. Tese (Doutorado em Planejamento Urbano e Regional) - Instituto de Planejamento Urbano e Regional, Universidade Federal do Rio de Janeiro, Rio de Janeiro, 2016.

SÁ, N. L. A. R. A cidade no despertar da era higiênica: a cidade da Parahyba e o movimento higienista (1854-1912). Dissertação (Mestrado em Geografia) - Universidade Federal da Paraiba, João Pessoa, 2009.

SANTOS, C. R. S. Dos negócios na cidade à cidade como negócio: uma nova sorte de acumulação primitiva no espaço. Cidades, São Paulo, v. 3, n. 5, p. 101-122, 2006. Disponível em: http://revista.fct.unesp.br/index.php/revistacidades/article/view/506/539. Acesso em: 8 abr. 2019.

SANTOS, M. A natureza do espaço: técnica e tempo, razão e emoção. 4. ed. São Paulo: Edusp, 2004.

SCHULZ, J. A crise financeira da abolição. Trad. Denis Augusto Fracalossi. 2. ed. São Paulo: Edusp, 2013.

SILVA, A. C. M. Do "entesouramento" à acumulação urbana: a produção do espaço de Fortaleza no século XIX. Tese (Doutorado em Geografia Humana) - Faculdade de Filosofia, Letras e Ciências Humanas, Universidade de São Paulo, São Paulo, 2005.

SILVA, L. O. Terras devolutas e latifúndio: efeitos da Lei de 1850. Campinas, SP: Ed. Unicamp, 1996. (Coleção Repositórios.)

TRAJANO FILHO, F. S. Do rio ao mar: uma leitura da cidade de João Pessoa entre duas margens. In: TINEM, N. Fronteiras, marcos e sinais: leituras das ruas de João Pessoa. João Pessoa: UFPB, 2006. p. 19-46.

VIDAL, W. C. L. Uma cidade em expansão: outros caminhos se definem. In: MOURA FILHA, M. B.; COTRIM, M.; CAVALCANTI FILHO, I. (Org.). Entre o rio e o mar: arquitetura residencial na cidade de João Pessoa. João Pessoa: Ed. UFPB, 2016. 
VIDAL, W. C. L. Transformações urbanas: a modernização da capital paraibana e o desenho da cidade, 1910-1940. Dissertação (Mestrado em Engenharia Urbana) - Universidade Federal da Paraiba, João Pessoa, 2004.

WILLIAMS, R. O campo e a cidade: na história e na literatura. São Paulo: Companhia das Letras, 2011.

Recebido em: 20 jul. 2021

Aprovado em: 13 set. 2021 